\title{
Factors Behind the Decline in the U.S. Natural Rate of Interest
}

Sungki Hong, Economist

Hannah G. Shell, Senior Research Associate

T he natural rate of interest is the real short-term rate that supports an economy operating at its potential output without increasing inflation. It is an essential benchmark rate for policymakers who determine the policy rate. If potential output declines, the natural rate declines with it. However, we do not directly observe the natural rate. Instead, we have to rely on quantitative models that describe the policy and economic activity of the government, households, and firms to uncover the underlying natural rate of interest.

\section{Longer lives and fewer babies have contributed to a lower natural rate of interest.}

The left panel of the figure plots the U.S. natural rate of interest, as estimated by Holston, Laubach, and Williams (2017). The rate starts out slightly below 6 percent in the early 1960s and tends to trend downward during the period, generally increasing during expansions and decreasing during recessions. In the 2007-09 recession, however, the rate drops quickly and does not increase at all during the following expansion.

What could be driving the long-run decline in the natural rate of interest? Over the past 30 years, demographics have changed in most developed countries as their populations have aged. This essay describes how changing demographics in the United States contribute to a decline in its natural rate.

\section{Changing Demographics}

The right panel of the figure shows three measures of U.S. demographic change: average life expectancy at birth (blue), the birth rate per 1,000 people (gray), and the old-age dependency ratio (orange), which is the population over age 65 divided by the population between ages 20 and 65 . Since the 1960s, life expectancy in the United States has increased by more than eight years. At the same time, the birth rate per 1,000 people has declined drastically, from 23.4 births in 1961 to 12.4 in 2015. Longer lives and slower population growth mean an aging population.

An aging population can present challenges. The last metric in the right panel, the old-age dependency ratio,

The Natural Rate of Interest and Demographics in the United States
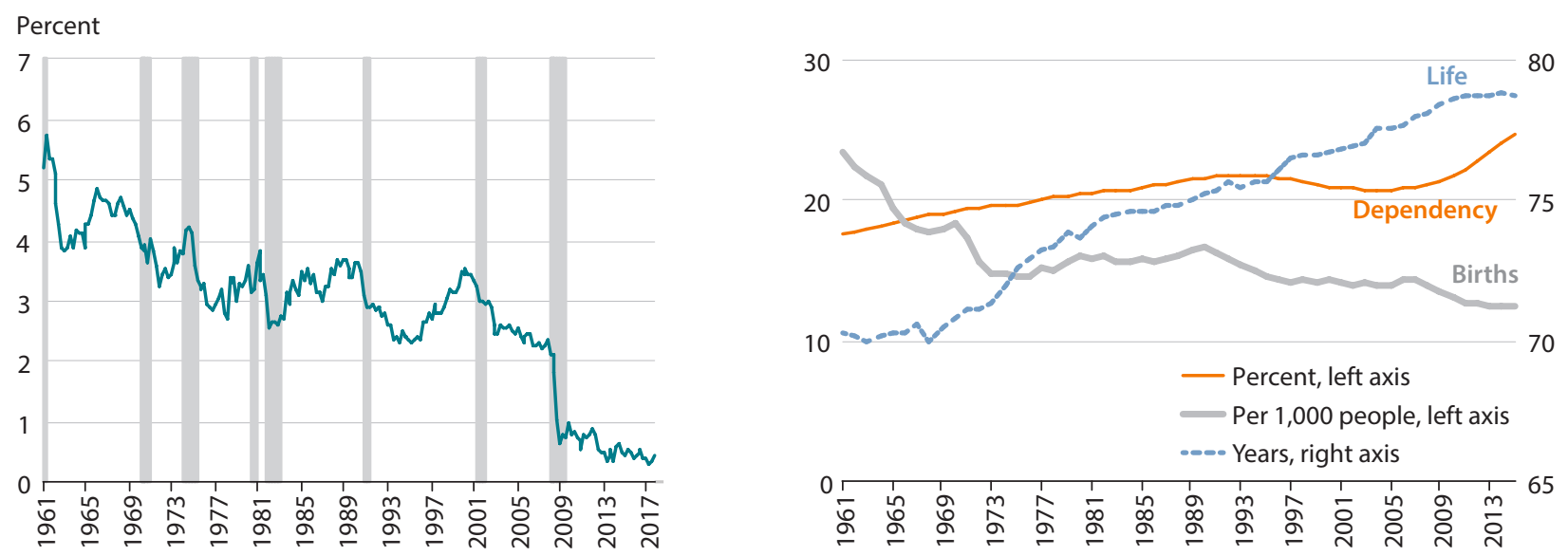

NOTE: Life, average life expectancy. Dependency, old-age dependency ratio. Gray bars indicate recessions as determined by the National Bureau of Economic Research. SOURCE: FRED ${ }^{\oplus}$, Federal Reserve Bank of St. Louis; World Bank, UN Population Database; Natural rate of interest estimated by Holston, Laubach, and Williams (2017). 
increased from 17 percent to just shy of 25 percent between 1961 and 2013. This increase puts a greater burden on the working-age population to support retirees. For example, the U.S. government supports retired individuals through payments such as Social Security. As the population ages, more individuals receive these payments than contribute toward them.

\section{Impact on the Natural Rate of Interest}

Demographics can affect the natural rate of interest through several channels. Remember, if potential output declines, the natural rate declines with it. An aging population and slowing population growth limit the supply of available workers in an economy. Therefore, holding labor productivity constant, a decrease in workers-a higher old-age dependency ratio-reduces the output generated by an economy. A smaller working-age population means fewer people with a lot of disposable income to consume. These factors decrease an economy's productive capacity and thereby lower the natural rate. U.S. labor force participation is up compared with the 1960s, despite a long decline since the mid-1990s. ${ }^{1}$ By itself, this rising labor force participation would tend to raise the natural rate by increasing productive capacity and, in turn, the natural rate of interest.

An aging population also impacts the natural rate of interest through the savings rate. A higher savings rate increases the supply of loanable funds that banks can lend out, therefore decreasing interest rates. As life expectancy increases, the time individuals spend in retirement increases as does the amount of money they will need to last through retirement. If working-age individuals believe social safety nets will fail, they are likely to save more to offset the risk. ${ }^{2}$ The U.S. savings rate did increase somewhat from 2005 to 2008; however, for the most part, U.S. household savings has declined since the 1970s.

\section{Conclusion}

Changing U.S. demographics can decrease the productive capacity of the economy through slowing labor force participation and population growth. Holding labor productivity constant, slowing participation and population growth lower potential gross domestic product (GDP) and the natural rate of interest. The natural rate could also be lower because of increased saving; however, Americans are saving less than they did 30 years ago. Most likely, changing U.S. demographics are reducing the U.S. natural rate of interest by decreasing potential output.

\section{Notes \\ 1 U.S. Bureau of Labor Statistics, Civilian Labor Force Participation Rate [CIVPART], retrieved from FRED, Federal Reserve Bank of St. Louis; https://fred.stlouisfed.org/series/CIVPART, accessed March 8, 2019. \\ 2 See Carvalho, Ferrero, and Nechio (2017).}

\section{References}

Carvalho, Carlos; Ferrero, Andrea and Nechio, Fernanda. "Demographic Transition and Low U.S. Interest Rates." Federal Reserve Bank of San Francisco FRBSF Economic Letter, 2017-17, September 2017;

https://www.frbsf.org/economic-research/publications/economic-letter/2017/september/demographic-transition-and-low-us-interest-rates/.

Holston, Kathryn; Laubach, Thomas and Williams, John C. "Measuring the Natural Rate of Interest: International Trends and Determinants." Journal of International Economics, 2017, 108, pp. S59-S75. 